Abstracta Iranica Abstanica

Revue bibliographique pour le domaine irano-aryen

Volume 34-35-36 | 2017

Comptes rendus des publications de 2011-2013

\title{
Israel Finkelstein, Alexander Fantalkin. Khirbet Qeifaya: An Unsensational Archaeological and Historical Interpretation
}

\section{Astrid Nunn}

\section{(2) OpenEdition}

Journals

Édition électronique

URL : http://journals.openedition.org/abstractairanica/41613

DOI : $10.4000 /$ abstractairanica. 41613

ISSN : 1961-960X

Éditeur :

CNRS (UMR 7528 Mondes iraniens et indiens), Éditions de l'IFRI

Référence électronique

Astrid Nunn, «Israel Finkelstein, Alexander Fantalkin. Khirbet Qeifaya: An Unsensational Archaeological and Historical Interpretation", Abstracta Iranica [En ligne], Volume 34-35-36 | 2017, document 53, mis en ligne le 15 juillet 2016, consulté le 29 septembre 2020. URL : http://journals.openedition.org/ abstractairanica/41613 ; DOI : https://doi.org/10.4000/abstractairanica.41613

Ce document a été généré automatiquement le 29 septembre 2020.

Tous droits réservés 


\title{
Israel Finkelstein, Alexander Fantalkin. Khirbet Qeifaya: An Unsensational Archaeological and Historical Interpretation
}

\author{
Astrid Nunn
}

\section{RÉFÉRENCE}

Israel Finkelstein, Alexander Fantalkin. « Khirbet Qeifaya: An Unsensational Archaeological and Historical Interpretation ». Tel Aviv, 39, 2012, p. 38-63.

1 Khirbet Qeiyafa, situé à $20 \mathrm{~km}$ au nord de Lachish, est l'objet de fouilles depuis 2007 (cf. Abs. Ir. 32-33, c.r. $\mathrm{n}^{\circ}$ 70). Le débat sur les interprétations divergentes des résultats obtenus par les fouilles archéologiques n'est pas tout à fait récent. Trois clans se sont formés : Y. Dagan, puis Y. Garfinkel et S. Ganor (cf. Abs. Ir. 32-33, c.r. $\mathrm{n}^{\circ}{ }^{69}$ ) et maintenant I. Finkelstein et A. Fantalkin. Ces derniers font preuve de leur désaccord avec les fouilleurs sur la datation de la première cité et de ses casemates. Elles seraient plus anciennes et remonteraient au Fer I, d'où l'impossibilité d'y voir la Shaaraim biblique. La céramique prouve que ce site était encore partiellement habité à l'époque achéménide. 


\section{AUTEURS}

\section{ASTRID NUNN}

Université de Munich 